\title{
Treatment of cornual viable pregnancy with single dose methotrexate: Case report
}

\author{
Tek doz metotreksat ile tedavi edilen canlı kornual gebelik: Olgu Sunumu
}

\author{
Neval Yaman Görük ${ }^{1}$, Ahmet Göçmen ${ }^{1}$, Mustafa Gazi Uçar ${ }^{1}$, Senem Yaman Tunç², Özlem Tosun ${ }^{1}$ \\ ${ }^{1}$ Ümraniye Eğitim ve Araştırma Hastanesi, Kadın Hastalıkları ve Doğum Kliniği, İstanbul, Türkiye \\ ${ }^{2}$ Batman Özel Dünya Hastanesi, Kadın Hastalıkları ve Doğum Kliniği, Batman, Türkiye
}

\begin{abstract}
We herein report a case of cornual viable pregnancy that was successfully treated with a single dose methotrexate without the need for surgical intervention. A 37 yearold woman was diagnosed cornual pregnancy based on transvaginal ultrasound findings and hormonal assays. A single dose systemic methotrexate $\left(50 \mathrm{mg} / \mathrm{m}^{2}\right)$ was administered. No side effects were experienced. Early diagnosis of interstitial pregnancy can lead to conservative treatment options. Although the most effective methotrexate protocol for conservative treatment is uncertain we concluded that in the hemodynamically stable patient a single dose systemic methotrexate treatment is a useful and should be considered as the first line treatment. This is safe and highly effective management even though viable fetus or high level of human chorionic gonadotropin (B-hCG) was assigned. Hemodynamic stability is the most important criteria and that is directly correlated with the early diagnosis. Surgery can be avoided; however, with conservative management a longer and close followup is required. J Clin Exp Invest 2012; 3(1): 105-107
\end{abstract}

Key words: Cornual pregnancy, methotrexate, treatment, viable

\section{INTRODUCTION}

The term cornual pregnancy is used interchangeably as a synonym for interstitial pregnancies. Interstitial pregnancy is an extremely rare form of ectopic pregnancy and difficult to diagnose that accounts for up to 1 to $3 \%$ of all ectopic pregnancies. ${ }^{1}$ This location of ectopic pregnancy usually occurs following in vitro fertilization (IVF) and previous salpingectomy. Although it shares similar risk factors with tubal ectopic pregnancy, in most cases there are no apparent risk factors. ${ }^{2}$

Initial evaluation consists of hormonal assays and pelvic ultrasonography. The routine use of ultrasound for the assessment of pregnant women

\section{ÖZET}

Cerrahi müdahaleye gerek kalmadan tek doz metotreksat ile başarılı bir şekilde tedavi ettiğimiz kornual canlı gebeliği olan bir olguyu sunmaktayız. Ultrason bulguları ve horman ölçümleri ile kornual gebelik tanısını koyduğumuz 37 yaşındaki olgumuza tek doz sistemik metotreksat (50 mg/ $\mathrm{m}^{2}$ ) tedavisi uyguladık. Hiç bir yan ekti gözlenmedi. İnterstisyel gebelikte erken tanı konservatif tedavi seçeneklerine imkân sağlar. Her ne kadar konservatif tedavide en etkili metotreksat protokolü belirlenmiş olmasa da hemodinamik olarak stabil olgularda tek doz sistemik metotreksat tedavisinin etkin olduğu söylenebilir ve ilk tedavi seçeneği olarak göz önünde bulundurulabilir. Canlı gebelik veya yüksek düzeyde human koryonik gonadotropin (B-hCG) tespit edilmiş olsa da bu tedavi güvenli ve oldukça efektif bir yöntemdir. En önemli kriter hemodinamik stabilitedir ve bu da doğrudan erken tanı ile ilişkilidir. Cerrahiden kaçınılabilir ancak konservatif tedavilerde daha uzun ve yakın takip gereklidir.

Anahtar kelimeler: Kornual gebelik, metotreksat, canlı, tedavi

facilitates the early diagnosis before serious complication and allows the use of more conservative management, such as medical treatment or laparoscopic surgery. Cornual pregnancies are regarded as a medical emergency. There is a concern for uterine rupture secondary to the weakened myometrial wall, the rupture of cornu still may result lifethreatening massive hemorrhage despite advances in both diagnosis and therapy. The major mortality and morbidity is directly related with late onset of symptoms and late diagnosis.

Methotrexate is an effective form of treatment for tubal ectopic pregnancy in the hemodynamically stable patient, but in the interstitial pregnancy cases with severely damaged uteri the traditional 
treatment of interstitial pregnancy has been corneal resection or hysterectomy. ${ }^{3}$ Patients must be well selected and alternative treatment options to conserve fertility should be looked for. Laparoscopic procedures are increasingly being used. ${ }^{4,5}$ Single dose intramuscular methotrexate is another treatment options and may be the first line treatment in the manegement of unruptured cornual pregnancy even though viable fetus or high level B-hCG was assigned.

In this study we presented a case of cornual viable pregnancy with the serum B-hCG level 8096 $\mathrm{mIU} / \mathrm{mL}$ that was successfully treated with a single dose systemic methotrexate $\left(50 \mathrm{mg} / \mathrm{m}^{2}\right)$.

\section{CASE}

A 37 year-old, gravida 3 para 1, abortus 1 woman presented with 6 weeks amenorrhea. Serum B-hCG level was $8096 \mathrm{mlU} / \mathrm{mL}$. Transvaginal sonogram revealed a sac situated external to the endometrial cavity in the left cornua of the uterus containing an embryo measuring $3,5 \mathrm{~mm}$ with positive heart rate consistent with a 6-week pregnancy (Figure 1-2). No free fluid was noted at the cul-de-sac. On abdomino-pelvic examination, we found enlarged uterus as six weeks pregnancy and slight left adnexial tenderness. No guarding or rebound tenderness was noted. The patient was diagnosed cornual pregnancy and hospitalized. First laboratory findings were: hemoglobin $12.2 \mathrm{~g} / \mathrm{dL}$, hematocrit \%38,3 and other biochemical laboratory findings were normal. The monitoring of complete blood count was normal and vital signs of the patient were stable. A single dose intramuscular methotrexate $(50 \mathrm{mg} /$ $\mathrm{m}^{2}$ ) was administered with no contraindications to methotrexate therapy. On the 4th day after MTX administration, serum B-hCG concentration was 6401 $\mathrm{mIU} / \mathrm{mL}$. The fetal heart rate was negative on the control transvaginal sonogram. On the 7 th day after MTX administration, serum B-hCG concentration was $2360 \mathrm{mlU} / \mathrm{mL}$. The patient was taken to followup for weekly serum B-hCG measurements. After one week, serum B-hCG concentration was 287 $\mathrm{mIU} / \mathrm{mL}$. The other weekly B-hCG concentrations were $30,3 \mathrm{mlU} / \mathrm{mL}, 5,5 \mathrm{mlU} / \mathrm{mL}$ and $3,9 \mathrm{mIU} / \mathrm{mL}$ respectively. On the control transvaginal sonogram, we found degenerate mass measuring 32×25 mm on the left cornua of uterus (Figure 3 ).

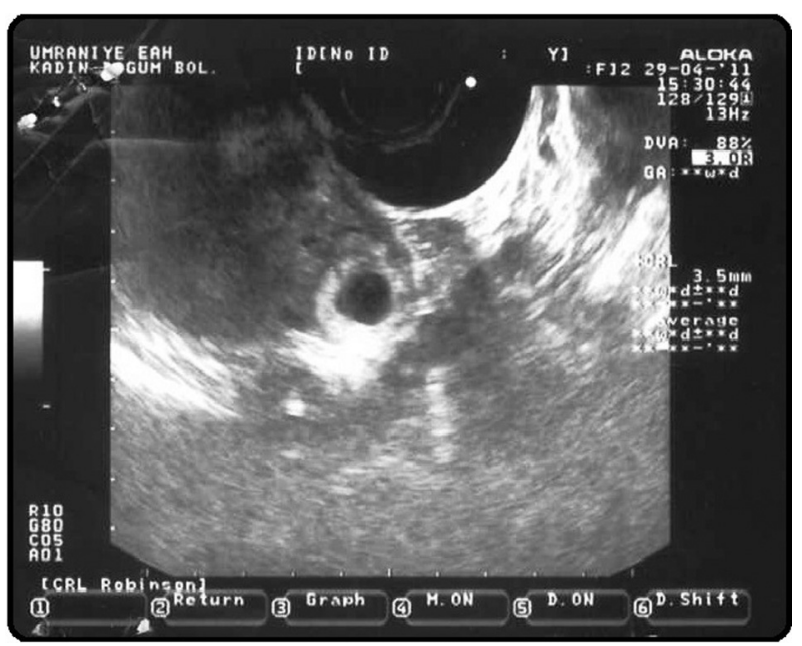

Figure 1. A sac situated external to the endometrial cavity in the left cornua of the uterus

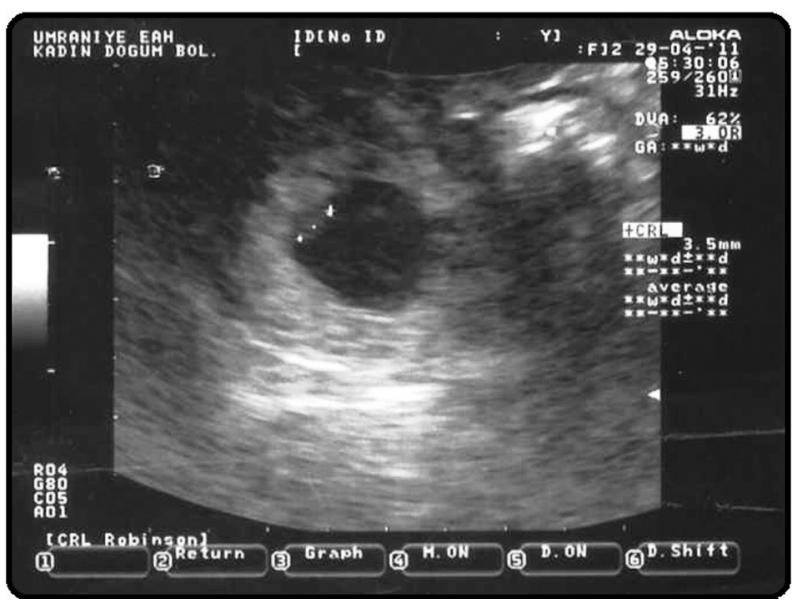

Figure 2. Embryo measuring $3,5 \mathrm{~mm}$ with positive heart rate consistent with a 6 -week pregnancy

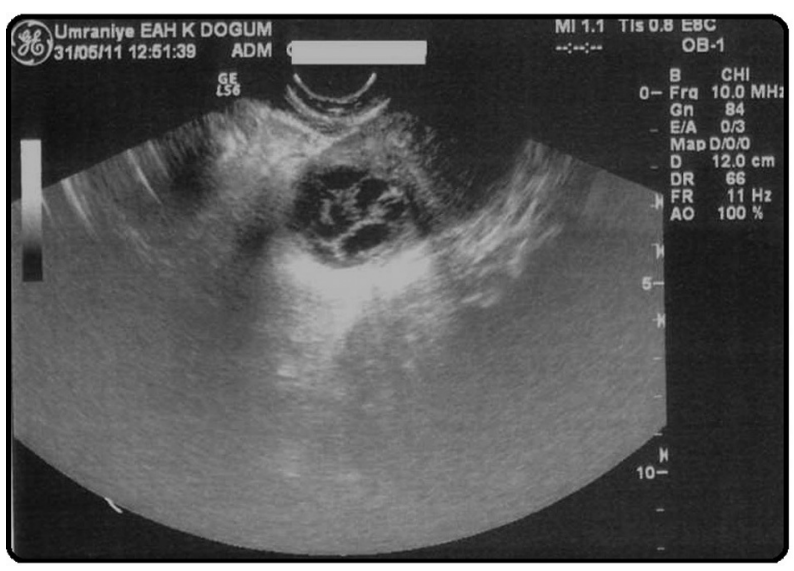

Figure 3. Degenerate mass measuring $32 \times 25 \mathrm{~mm}$ on the left cornua of uterus 


\section{DISCUSSION}

Diagnosis of interstitial pregnancies relies heavily on ultrasound and potentially on laparoscopic evaluation. ${ }^{6}$ A viable interstitial pregnancy may occasionally be misinterpreted as a normal intrauterine pregnancy. Therefore, it is important that strict diagnostic criteria are used in every case: empty uterine cavity and chorionic sac that is seen separately and more than $1 \mathrm{~cm}$ from the most lateral edge of the uterin cavity and surrounded by a myometrial layer. ${ }^{7}$ Diagnosis is challenging and requires a high index of suspicion. Commonly late diagnosis is due to more distensibility capacity of the myometrium at the cornu in which the interstitial part has a thin muscle layer. As this is a highly vascular area, may necessitate emergent laparotomy and hysterectomy due to hemorrhage at surgery. ${ }^{8}$ Previously, interstitial pregnancies were diagnosed only at laparotomy following the rupture. ${ }^{9}$ For the reason of major hemorrhage hysterectomy rate was higher. ${ }^{9}$

Traditionally interstitial pregnancies have been diagnosed late and managed by open surgery. ${ }^{3}$ However, there are successful case reports of laparoscopic resection of corneal pregnancies. ${ }^{5,6,11,12}$ In these cases with severely damaged uteri the traditional treatment has been corneal resection or hysterectomy. ${ }^{3}$ Early diagnosis of interstitial pregnancy can lead to conservative treatment options. Conservative treatment has replaced hysterectomy and more conservative approaches had been advocated recently. ${ }^{5}$ Although surgical management of interstitial pregnancy has remained most common, methotrexate has been used in the treatment. Only a small number of case reports have described medical treatment of interstitial ectopic pregnancies. ${ }^{10,11}$ Almost all of the reported patients were treated with repeated high doses $(1 \mathrm{mg} / \mathrm{kg}$ ) of methotrexate. ${ }^{10,11}$ Altough there are reports of successful treatment with single-dose methotrexate injection; and also reports of failures. . $^{5,111,12}$ According to our monitoring of patients, single dose methotrexate has proven to be successful and cost effective alternative to traditional surgical management of interstitial pregnancy.

Fisch et al. concluded that methotrexate is a safe option but the failure rate is high. ${ }^{10}$ So close monitoring is essential because rupture is possible even after treatment has begun and a longer follow-up is required. Patient must be informed about extended follow-up. There is no consensus on the dose or number of methotrexate injections that should be used in the treatment of interstitial pregnancies. ${ }^{10-12}$ Jermy $\mathrm{K}$ et al. suggested that when the initial serum B-hCG is greater than $5000 \mathrm{IU}$, a second systemic dose of methotrexate is likely to be required for a successful outcome. ${ }^{12}$ Conversely in our case initial serum B-hCG was $8096 \mathrm{mlU} / \mathrm{mL}$ and treated without the need for surgical intervention and repeted doses.

In conclusion, in selected patients conservative treatment, when possible, should be considered. Single dose methotrexate is cost effective and alternative to traditional surgical management of interstitial pregnancy. In the hemodynamically stable patient methotrexate is a safe option and may be the first line treatment in the management of unruptured cornual pregnancy even though viable fetus or high level of human chorionic gonadotropin (B-hCG) was assigned. Surgery can be avoided; however a longer and close follow-up is required. Hemodynamic stability is the most important criteria and that was directly correlated with the early diagnosis.

\section{REFERENCES}

1. Vicino M, Loverro G, Resta L, Bettocchi S, Vimercati A, Selvaggi $L$. Laparoscopic cornual excision in a viable large interstitial pregnancy without blood flow detected by color Doppler ultrasonography. Fertil Steril 2000;74(2):407-9.

2. Siow $\mathrm{A}, \mathrm{Ng} \mathrm{S}$ Laparoscopic management of 4 cases of recurrent cornual ectopic pregnancy and review of literature. J Minim Invasive Gynecol 2011;18(3):296-302.

3. Katz D L. Barrett J P. Sanfilippo J S. Badway D M. Combined hysteroscopy and laparoscopy in the treatment of interstitial pregnancy. Am J Obstet Gynecol 2003;188(4)1113-4.

4. Erdem A. Laparoscopic Tubal Surgery [Laparoskopik Tubal Cerrahi]. Türkiye Klinikleri J Gynecol Obst-Special Topics 2008;1(6):11-7.

5. Larraín D, Marengo F, Bourdel N, Jaffeux P, et al. Proximal ectopic pregnancy: a descriptive general population-based study and results of different management options in 86 cases. Fertil Steril 2011;95(3):867-71.

6. MacRae R, Olowu O, Rizzuto MI, Odejinmi F. Diagnosis and laparoscopic management of 11 consecutive cases of cornual ectopic pregnancy. Arch Gynecol Obstet 2009;280(1):5964.

7. Timor-Tritsch IE, Monteagudo A, Matera C, Veit C. Sonographic evaluation of cornual pregnaacies treated without surgery. Obstet Gynecol 1992;79(6):83-7.

8. Brewer H, Gefroh S, Bork M, Munkarah A, Hawkins R, Redman M. Asymptomatic rupture of a cornual ectopic in the third trimester. J Reprod Med 2005;50(9):715-8.

9. Harika G, Gabriel R,Carre- Pigeon F, et al. Primary application of three -dimensional ultrasonography to early diagnosis of ectopic pregnancy .Eur J Obstet Gynecol Reprod Biol 1995;60(2):117-20.

10. Fisch J D. Ortiz B, Tazuke S, Chitkara U, Giudice L. Medical management of interstitial ectopic pregnancy: a case report and literature review. Hum Reprod 1998;13(7):1981-6.

11. Gherman RB, Stitely M, Larrimore C, Nevin K, Coppola A, Wiese D. Low-dose methotrexate treatment for interstitial pregnancy. A case report. J Reprod Med 2000;45(2):142-4.

12. Jermy K, Thomas J, Doo A, Bourne T. The conservative management of interstitial pregnancy. BJOG 2004;111(11):12838. 